\title{
Mast cells play a pivotal role in ischaemia reperfusion injury to skeletal muscles
}

\author{
Susan K Bortolotto ${ }^{1}$, Wayne A Morrison ${ }^{1,2}$, XiaoLian Han ${ }^{1}$ and Aurora Messina ${ }^{1}$ \\ ${ }^{1}$ Bernard O'Brien Institute of Microsurgery, St Vincent's Hospital, Victoria, Australia and ${ }^{2}$ Department of \\ Surgery, University of Melbourne, Victoria, Australia
}

\begin{abstract}
Ischaemia reperfusion (IR) injury is a serious complication of cardiovascular disease, transplantation and replantation surgery. Once established there is no effective method of treatment. Although studies using mast cell-depleted $\left(W^{f} / W^{f}\right)$ mice implicate mast cells in this pathology, they do not exclude a contribution by other deficiencies expressed in $W^{f} / W^{f}$ mice. In order to obtain conclusive evidence for the role of mast cells, we engrafted cultured bone marrow-derived mast cells (BMMC) from normal mice into their $\mathbf{W}^{t} / \mathrm{W}^{f}$ littermates. After 12 weeks, the hind limbs of $W^{t} / W^{f}$, engrafted $W^{t} / W^{f}$ and normal littermates were subjected to IR injury. Muscle viability was assessed by both morphology and by nitroblue tetrazolium histochemical assay. Here, we present conclusive evidence for a causal role of mast cells in IR injury. Our data show that muscles from $\mathbf{W}^{t} / \mathbf{W}^{f}$ mice subjected to IR have a significantly greater proportion of viable fibres than normal littermates subjected to identical injury $\left(78.9 \pm 5.2\right.$ vs $27.2 \pm 3.7 \%$, respectively). When $W^{f} / W^{f}$ IR-resistant mice were engrafted with BMMC from normal littermates and subjected to IR, the proportion of viable muscle fibres was significantly reduced (78.9 \pm 5.2 vs $37.0 \pm 6.5 \%)$. Thus, engraftment of $B M M C$ into $W^{f} / W^{f}$ mice restores the susceptibility of skeletal muscle to IR injury irrespective of other abnormalities in $W^{t} / W^{f}$ mice. In this model, the numerical density of mast cells undergoes a significant decrease within $1 \mathrm{~h}$ of reperfusion, indicating extensive mast cell degranulation. We conclude that mast cells are pivotal effector cells in the pathogenesis of IR injury of murine skeletal muscle.
\end{abstract}

Laboratory Investigation (2004) 84, 1103-1111, advance online publication, 7 June 2004; doi:10.1038/labinvest.3700126

Keywords: mast cells; engraftment; ischaemia reperfusion injury; mast cell-depleted mice; skeletal muscle

Ischaemia reperfusion (IR) injury is a significant cause of morbidity following traumatic injury and a major complication following transplantation of organs and replantation of severed limbs. The ischaemic phase results in cell death, but if cells survive this insult the reperfusion has further deleterious effects on their survival. Irrespective of measures taken to reduce exposure of the tissue to an ischaemic phase, the inevitable reintroduction of blood flow causes irreversible injury for which there is no treatment. Reperfusion also returns the toxic metabolites to the circulation exacerbating local and inducing distant tissue injury (for a review see Grace $^{1}$ ). Oxygen radicals and neutrophils were the first mediators to be implicated, however, their role now appears to be secondary. ${ }^{2}$ More recently identified mediators are nitric oxide (NO) and mast

Correspondence: Dr SK Bortolotto, PhD, Bernard O’Brien Institute of Microsurgery, 42 Fitzroy St., Fitzroy, 3065 Victoria, Australia. E-mail: Susan.BORTOLOTTO@svhm.org.au

Funding: National Health and Medical Research Council of Australia Grant \# 209113.

Received 28 December 2003; revised 26 February 2004; accepted 12 March 2004; published online 7 June 2004 cells. ${ }^{3,4}$ Our studies in rats demonstrated that the NO involved in IR injury was derived from NO synthase II (NOS II) and the use of NOS II inhibitors greatly improved survival of gastrocnemius skeletal muscle subjected to IR. $^{3}$ In ongoing IR studies it was revealed that NOS II protein was almost exclusively localized in mast cells, ${ }^{5,6}$ and that the number of markedly degranulated mast cells increased within hours of reperfusion. Recent studies by Gilchrist et $a l,{ }^{7}$ confirm the presence of NOS II protein and mRNA in rat peritoneal mast cells.

More recently, we and others have shown that skeletal muscles from mast cell-depleted/deficient mouse strain are remarkably resistant to IR injury compared with their normal littermates. ${ }^{8,9}$ In our laboratory, the IR-injured gastrocnemius muscle viability was $94 \%$ in mast cell-depleted $\left(\mathrm{W}^{\mathrm{f}} / \mathrm{W}^{\mathrm{f}}\right)$ mice compared to only $9 \%$ in control mice. ${ }^{8}$ This observation was confirmed in a brief report by Mukundan et $a l^{9}$ in the hind limbs of mast celldeficient $\left(\mathrm{W} / \mathrm{W}^{\mathrm{v}}\right)$ mice. Mast cells are heterogeneous and complex cells, packed with dense granules, capable of degranulation within seconds after activation and releasing mediators that activate numerous biological functions. They are most 
commonly known and studied for their roles in inflammation and allergic reactions. However, mast cells are important in other pathologies. ${ }^{10}$ Indirect evidence implicate mast cells in IR injury of several tissues, including intestine ${ }^{11}$ and more commonly heart. ${ }^{12}$ However, the extent to which mast cells are involved in IR injury is not conclusively established in these studies using mast cell-depleted/deficient mice because they carry other deficiencies that may contribute to the results observed. In general, mast cell-deficient mice not only lack mast cells in all resident tissues $(<10 \%),{ }^{13}$ but they are also anaemic, lack melanocytes and are sterile. A unique opportunity to study the role of mast cells in different pathologies is available by the use of mast cell-deficient mice. These mice arise from a natural mutation to the cell surface receptor c-kit, resulting in a lack of response to stem cell factor (SCF), which is important to the migration, proliferation, survival and maturation of cells. There are several strains of mast cell-deficient mice, the most commonly used are mast cell-deficient $\left(\mathrm{W} / \mathrm{W}^{\mathrm{v}}\right)$ mice that have several mutations of c-kit. In this study, we use the $\mathrm{W}^{\mathrm{f}} / \mathrm{W}^{\mathrm{f}}$ strain in which c-kit contains a single-point mutation. The gastrocnemius muscles of these mice do not contain mast cells.

It is possible to engraft mast cell-depleted mice with littermate-derived bone marrow to restore the mast cell population. The replantation of mast cells into $\mathrm{W} / \mathrm{W}^{\mathrm{v}}$ mice was first described by Kitamura et $a l,{ }^{13} 15$ weeks after transplanting bone marrow from control mice. In this study, mast cell density increased in several tissues to similar levels as in control mice. However, bone marrow transplantation leads to the correction of all haematological disorders associated with these mice, including anaemia and other nonmast cell-related deficiencies. As first discovered by Nakano et $a{ }^{14}{ }^{14}$ it is possible to culture mast cells in vitro from bone marrow of normal mice and transfer them into $\mathrm{W} / \mathrm{W}^{\mathrm{v}}$ to repopulate tissues. This study, demonstrated a unique opportunity to study mast cells in vivo because only the mast cell deficiency is corrected. By engrafting cultured bone marrow-derived mast cells (BMMC) into $\mathrm{W} / \mathrm{W}^{\mathrm{v}}$, several groups have demonstrated the importance of mast cells in pathologies such as UV irradiation, ${ }^{15}$ multiple sclerosis, ${ }^{16}$ inflammatory disease ${ }^{17}$ and murine asthma. ${ }^{18}$

In this study, we show that the mast cells in gastrocnemius muscles of normal mice undergo a significant decrease in numerical density, within $1 \mathrm{~h}$ of reperfusion. To further investigate the role of mast cells in skeletal muscle IR injury, we injected BMMC into $\mathrm{W}^{\mathrm{f}} / \mathrm{W}^{\mathrm{f}}$ mice and allowed 12 weeks for engraftment. We then subjected these mice, age-matched $\mathrm{W}^{\mathrm{f}} / \mathrm{W}^{\mathrm{f}}$ and normal littermate mice to $70 \mathrm{~min}$ warm ischaemia, followed by a reperfusion period of $24 \mathrm{~h}$ or 3 days. Our study reveals that skeletal muscles of $\mathrm{W}^{\mathrm{f}} / \mathrm{W}^{\mathrm{f}}$ mice recovered their susceptibility to IR injury after engraftment with BMMC, to levels comparable with normal littermates. This is conclusive evidence that mast cells play a pivotal role in IR injury of skeletal muscle.

\section{Materials and methods}

\section{Animals}

Mast cell-depleted, $\mathrm{W}^{\mathrm{f}} / \mathrm{W}^{\mathrm{f}}$, and normal littermate mice were bred from mating $\left(\mathrm{C} 57 \mathrm{BL} / 6 \mathrm{~W}^{\mathrm{f}} \times \mathrm{DBA} /\right.$ $\left.2 \mathrm{~W}^{\mathrm{f}}\right) \mathrm{F}_{1}$ hybrids. $\mathrm{W}^{\mathrm{f}} / \mathrm{W}^{\mathrm{f}}$ and normal littermates were identified by coat colour (homozygous littermates, black coat; homozygous $\mathrm{W}^{\mathrm{f}} / \mathrm{W}^{\mathrm{f}}$, white coat; heterozygous littermates, black coat with white spots). Original breeding pairs were obtained from Associate Professor Prue Hart, Flinders University, South Australia. C57/Bl6 mice were purchased from Animal Resources Centre, Perth, Western Australia. Mice were housed at St Vincent's Hospital, Melbourne with food and water given ad libtum, and housed in a $12 \mathrm{~h}$ day/night cycle. All experiments and breeding were conducted in accordance with the guidelines of the Animal Ethics Committee of St Vincent's Hospital, Melbourne, and National Health \& Medical Research Council of Australia.

\section{Cell Culture of BMMC and Engraftment}

Mice were anaesthetized and the femurs on both sides harvested under aseptic conditions. The marrow was flushed from the femurs by injecting media into one end using a 23 gauge needle attached to a syringe. The harvested bone marrow was washed, spun and the cell suspension cultured in a $25 \mathrm{~cm}^{2}$ culture flask at $1 \times 10^{5} \mathrm{cell} / \mathrm{ml}$. Cells were cultured in complete DMEM media (Gibco Lifetechnology, INVITROGEN) containing $10 \%$ foetal calf serum (FCS, CSL Ltd., Australia), $292 \mu \mathrm{g} / \mathrm{ml}$ glutamine (SIGMA Aldrich), $100 \mathrm{U} / \mathrm{ml}$ penicillin $\mathrm{G}$ and $100 \mu \mathrm{g} / \mathrm{ml}$ streptomycin sulphate (Gibco Lifetechnology, INVITROGEN) and with the addition of recombinant mouse interleukin-3 (IL-3) and recombinant mouse SCF $(10 \mathrm{ng} / \mathrm{ml}$ and $12.5 \mathrm{ng} / \mathrm{ml}$ respectively, R\&D Systems Inc.). Nonadherent cells were transferred weekly into fresh complete media containing SCF and IL-3. BMMC were derived for 4 weeks after which $>95 \%$ appeared metachromatic with toluidine blue staining. Immunohistochemistry staining for c-kit receptor was carried out to confirm the proportion of mast cells in the BMMC. This analysis showed that $98.5 \%$ (total counted 1131 cells) were c-kit positive. BMMC were all homogenously round in shape and contained granules. BMMCs $\left(1 \times 10^{7}\right.$ cells in $200 \mu$ l media $)$ were injected intravenously via the tail vein of $\mathrm{W}^{\mathrm{f}} / \mathrm{W}^{\mathrm{f}}$ mice. Mice were housed with their age matched normal and $\mathrm{W}^{\mathrm{f}} / \mathrm{W}^{\mathrm{f}}$ littermates for 12 weeks to permit mast cell engraftment. 


\section{Immunohistochemistry}

BMMC were smeared onto poly-L-lysine slides and fixed with $4 \%$ paraformaldehyde for $1 \mathrm{~min}$. After fixation, cells were rinsed in TBS $+0.05 \%$ Tween 20 incubated with the primary antibody, CD117 (clone ACK 45, PharMingen) at $20 \mu \mathrm{g} / \mathrm{ml}$ diluted in TBS $+1 \%$ BSA for $1 \mathrm{~h}$ at RT. The cells were rinsed in TBS $+0.05 \%$ Tween 20 and then incubated for $30 \mathrm{~min}$ at RT with rabbit anti-rat IgG conjugated to horseradish peroxidase (DAKO) diluted to $13 \mu \mathrm{g} / \mathrm{ml}$ in TBS. Cells were washed in TBS $+0.05 \%$ Tween 20 and colour reaction formed with liquid DAB (DAKO). Cells incubated without primary antibody served as controls. None of the controls were immunolabelled.

\section{Blood Analyses}

Eye bleeds were collected for haematocrit (HCT) determination to assess the anaemia of $\mathrm{W}^{\mathrm{f}} / \mathrm{W}^{\mathrm{f}}$ mice before and after engraftment of BMMCs. Blood was also taken from normal littermate and $\mathrm{W}^{\mathrm{f}} / \mathrm{W}^{\mathrm{f}}$ mice. Whole blood assays were performed on a SYSMEX (FE 9000) automated machine at the Department of Pathology, St Vincent's Hospital, Melbourne.

\section{IR Model in Mice}

Mice were anaesthetized by intraperitoneal (i.p.) injection of $4 \%$ chloral hydrate $(0.1 \mathrm{ml} / 10 \mathrm{~g}$ body weight), followed by i.p. injection of an analgesic to minimize postoperative pain. Warm ischaemia was induced by placing $2 \times$ size eight rubber bands (wound three times) high on the right hind limb of the mouse, well clear of the muscles of interest. Previous data show that this induces whole limb ischaemia and there is minimal blood flow to the muscle and bone. ${ }^{3}$ During the $70 \mathrm{~min}$ ischaemia, a needle thermistor probe was inserted subcutaneously on the right leg, and the hind limb temperature was maintained at $36 \pm 1{ }^{\circ} \mathrm{C}$ with a tungsten heating lamp. Controlled temperature was used during ischaemia to maintain consistency throughout experiments. Normal littermates, $W^{f} / W^{f}$ and engrafted $W^{f} / W^{f}$ mice underwent IR in pairs simultaneously to minimize day-to-day variation. After ischaemia, the bands were removed and the mice allowed to recover at normal room temperature for $24 \mathrm{~h}$ reperfusion (for muscle viability assessment by nitro blue tetrazolium (NBT) assay and morphology) or 3 days reperfusion (morphological assessment of necrotic fibres). After this period, the mice were reanaesthetized and the gastrocnemius, extensor digitorum longus (EDL) and soleus muscles were removed before the mouse was sacrificed. Muscles were weighed and their volume measured by fluid displacement. ${ }^{19}$ Briefly, a small beaker was $2 / 3$ filled with $0.9 \% \mathrm{NaCl}$. Taking care not to touch the edges of the beaker, the muscle was completely submerged while suspended on a thin thread. The weight of the fluid displacing the muscle was relative to the muscle volume (specific gravity of isotonic saline is 1.0048).

\section{Muscle Viability}

The nitro blue tetrazolium (NBT) assay was used to measure muscle viability in whole mounts of skeletal muscle. This histochemical assay labels mitochondrial oxidative enzyme activity with a blue reaction product. Muscles were sliced into five equal cross-sections immediately after they were removed. Two cross-sections systematically selected from different areas of the treated and contralateral muscles were placed into $0.033 \%$ NBT solution in PBS (SIGMA) and the reaction was started by the addition of $1.9 \mathrm{mM} \mathrm{NADH}$ in $\mathrm{H}_{2} \mathrm{O}$ (SIGMA). Incubation was carried out at room temperature for $20 \mathrm{~min}$ with constant agitation, after which muscle crosssections were immediately fixed in 10\% buffered formal saline (BFS). Muscle cross-sections were analysed with the aid of a dissecting microscope ( $\times 40$ magnification). The proportion of viable tissue was calculated by standard point counting technique. A minimum of 100 points were counted for each muscle cross-section. Each of the four muscle cross-sections were viewed under $\times 40$ magnification with a grid overlay $(10 \times 10)$ placed in the eyepiece. The number of points (line intersections) that fell on viable and nonviable fibres were counted and scored separately. The proportion of viable fibres was calculated for each face, summed up and averaged for each muscle. The proportion of viable tissue of treated vs contralateral muscles was then calculated for each mouse and the mean calculated for each group where $n=$ number of mice.

\section{Histology}

For histological analysis, all tissues were immersion-fixed for $24 \mathrm{~h}$ in $10 \% \mathrm{BFS}$, after which they were washed in PBS and processed routinely for embedding in paraffin. Sections $5 \mu \mathrm{m}$ thick were cut, mounted and stained with haematoxylin and eosin (H\&E).

\section{Assessment of Necrotic Muscle}

The gastrocnemius muscles from some mice underwent $70 \mathrm{~min}$ warm ischaemia followed by 3 days reperfusion (as described above). This longer period of reperfusion permits the necrotic muscle fibres to be clearly identified in H\&E sections and this time point precedes muscle regeneration events. No regenerating fibres were observed in any of the specimens analysed. The percentage volume density of necrotic fibres, healthy fibres and extracellular space was assessed by point counting of $\mathrm{H} \& \mathrm{E}$ 
sections. Muscle cross-sections were viewed by microscopy and the image was captured on a highresolution monitor at a final magnification of $\times 100$ via a digital video camera (JVC, TK C1480E) attached to a microscope. A nine-point grid was computer generated using the CAST system (Olympus, Denmark) and overlaid on the microscope image. With the aid of an electronic stepping stage (H128, Prior Scientific, Rockland, USA) a series of systematic fields were sampled such that $25 \%$ of the specimen was assessed with a minimum of 200 points/specimen. The number of points falling on necrotic fibres/healthy fibres/extracellular space were counted and expressed as a percentage of the total number of points per section. In addition, tissue volume (expressed as microlitres) of necrotic fibres, healthy fibres and extracellular space was calculated by multiplying individual percentages (determined above) by gastrocnemius muscle volume.

\section{Leucocyte Profiles}

Leucocytes were counted from the gastrocnemius muscle from littermates, $\mathrm{W}^{\mathrm{f}} / \mathrm{W}^{\mathrm{f}}$ and engrafted $\mathrm{W}^{\mathrm{f}} / \mathrm{W}^{\mathrm{f}}$ mice that underwent $70 \mathrm{~min}$ ischaemia and $24 \mathrm{~h}$ reperfusion ( $n=3$ /group). With the aid of the microscope system as used above to assess for necrotic muscle, a minimum of 150 leucocytes were counted per specimen using the $\times 60$ objective. Results were expressed as leucocyte profiles $/ \mathrm{mm}^{2}$.

\section{Mast Cell Staining}

Histochemical staining with toluidine blue and chloroacetate esterase was performed to identify mast cells in tissues. For toluidine blue, $5 \mu \mathrm{m}$ paraffin sections were stained for $5 \mathrm{~min}$ with $0.5 \%$ w/v toluidine blue, $\mathrm{pH} 3.0$ (ProSciTech). Mast cells were clearly identified by their granules which exhibit metachromatic pink/purple staining. ${ }^{20}$ Chloroacetate esterase specifically stains esterases in the mast cell granules. ${ }^{21}$ The paraffin sections, once rehydrated, were incubated for $30 \mathrm{~min}$ in a freshly filtered sodium phosphate buffer solution containing $\quad 0.013 \%$ pararosanilin-HCl (SIGMA), $0.013 \%$ sodium nitrite (SIGMA) and $0.034 \%$ napthol AS-D chloroacetate (SIGMA) in $\mathrm{N}$-dimethylformamide. After incubation, the sections were washed and counter-stained with haematoxylin for 5 min. Mast cells appear a brilliant red colour. With the aid of the microscope system as used above mast cell profiles in a minimum of 16 sections from each muscle were counted using the $\times 40$ objective.

\section{Mast Cell Profiles in Reperfused Injured Muscle}

Hind limbs of C57Bl/6 mice underwent warm ischaemia as described above. After 0, 0.5, 1, 2, 4,
8 and 24 h of reperfusion mice were sacrificed and skeletal muscles dissected. Gastrocnemius muscles were processed for histology as described above and sections were stained with toluidine blue. To correct for oedema, the percentage of muscle to extracellular space was calculated and mast cell profiles expressed as mast cells $/ \mathrm{mm}^{2}$ muscle. A minimum of 100 mast cells in each muscle were counted.

\section{Statistical Analyses}

Statistical analyses were performed using GraphPad Prism (software for Science, version 4) and SPSS software (Statistical Package for the Social Sciences, version 11.5). All results are expressed as means \pm s.e. of the mean (s.e.m.) of grouped data where $n=$ number of mice/group. For comparison of two groups, means were analysed by paired Student's $t$-test. For groups of three, comparison was performed with ANOVA followed by the Bonferroni post hoc test. For comparison of necrosis at 3 days reperfusion, a one-way ANOVA followed by Student-Newman-Keuls post hoc analysis was performed. A probability level of $P<0.05$ was taken to indicate statistical significance.

\section{Results}

\section{BMMC Engraftment of $\mathbf{W}^{\mathrm{f}} / \mathrm{W}^{\mathrm{f}}$ Mice Restores IR Injury}

The NBT assay was applied to whole mount crosssections of skeletal muscle that were exposed to $70 \mathrm{~min}$ ischaemia and $24 \mathrm{~h}$ reperfusion to determine mitochondrial activity and hence muscle viability. The gastrocnemius, soleus and EDL muscles were assayed in each group. Muscle viability was significantly reduced from an average of $79 \pm 5 \%\left(\mathrm{~W}^{\mathrm{f}} /\right.$ $\mathrm{W}^{\mathrm{f}}$ muscles) to $37 \pm 7 \%$ (engrafted $\mathrm{W}^{\mathrm{f}} / \mathrm{W}^{\frac{\mathrm{f}}{m}}$ muscles) and $27 \pm 4 \%$ (normal littermate muscles) (pooled data from all muscle types tested). The results for each individual muscle type are shown in Figure 1. In particular, the viability of gastrocnemius (Figure 1b) and EDL (Figure 1c) muscles of BMMC engrafted $\mathrm{W}^{\mathrm{f}} / \mathrm{W}^{\mathrm{f}}$ mice was significantly less than that observed in their normal littermates.

\section{Blood Analyses}

The haematocrit level of mice was measured to determine if engraftment of mast cells corrected the anaemia. Blood analyses showed that BMMC engraftment of $\mathrm{W}^{\mathrm{f}} / \mathrm{W}^{\mathrm{f}}$ mice did not correct for anaemia. The haematocrit levels were $49.2 \pm 2.6 \%$ (normal littermates), $37.0 \pm 6.7 \%\left(\mathrm{~W}^{\mathrm{f}} / \mathrm{W}^{\mathrm{f}}\right)$ and $32.6 \pm 3.0 \%$ (BMMC engrafted $\mathrm{W}^{\mathrm{f}} / \mathrm{W}^{\mathrm{f}}$ ). 


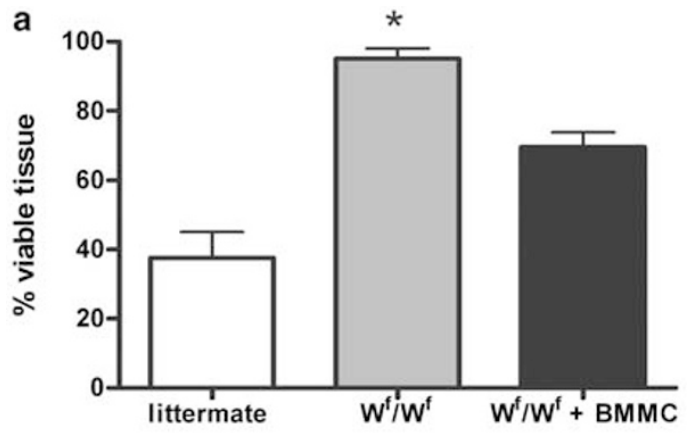

b
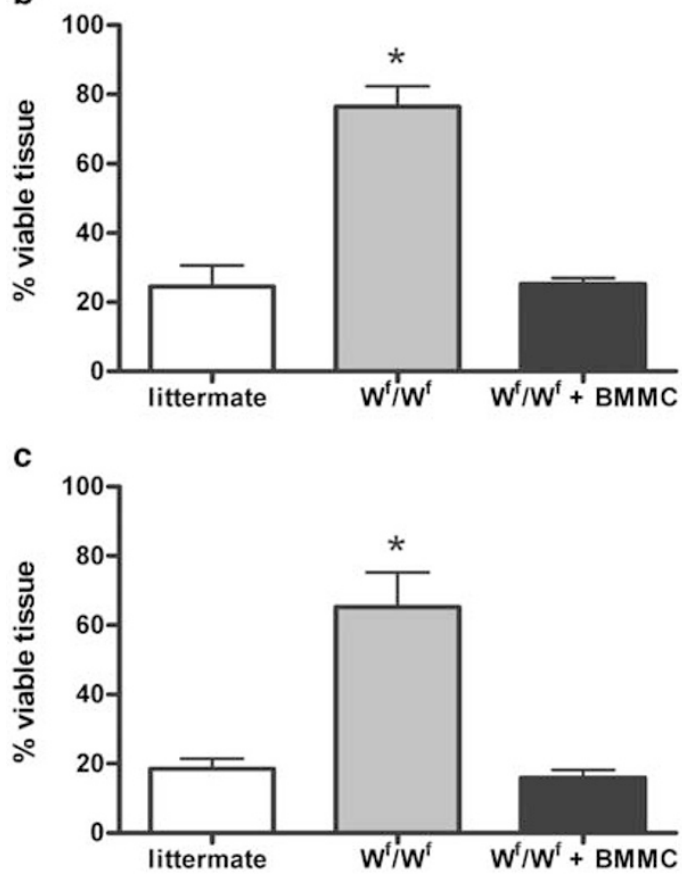

Figure 1 Percentage of muscle viability after $70 \mathrm{~min}$ ischemia and $24 \mathrm{~h}$ reperfusion as assessed by NBT assay on whole mounts. Viability of the treated muscle expressed as a proportion of viability of contralateral control muscle in the soleus (a), gastrocnemius (b) and extensor digitorum longus (c) muscles. Normal littermates, $n=8-9 ; \mathrm{W}^{\mathrm{f}} / \mathrm{W}^{\mathrm{f}}, n=4 ; \mathrm{W}^{\mathrm{f}} / \mathrm{W}^{\mathrm{f}}+\mathrm{BMMC}, n=5$. Values are mean \pm s.e.m. ${ }^{*}$ Significantly different to littermate and $\mathrm{W}^{\mathrm{f}} / \mathrm{W}^{\mathrm{f}}+$ BMMC $(P<0.05)$.

\section{Muscle Histology}

Paraffin cross-sections of gastrocnemius muscle were stained with $\mathrm{H} \& \mathrm{E}$ for morphologic assessment. Representative photos show that after $24 \mathrm{~h}$ reperfusion, the muscle morphological appearance from normal littermates (Figure 2a), $W^{f} / W^{f}$ (Figure 2b) and engrafted $W^{f} / W^{f}$ mice (Figure $2 c$ ) was similar. In all groups only a small proportion of muscle fibres was necrotic and the majority of fibres appeared healthy. However, after 3 days reperfusion, the $\mathrm{W}^{\mathrm{f}}$ / $\mathrm{W}^{\mathrm{f}}$ muscle (Figure 2e) contained a large proportion of healthy fibres and only a small proportion of necrotic and 'moth eaten' fibres. In comparison, the muscle from the normal littermate (Figure 2d) and engrafted $\mathrm{W}^{\mathrm{f}} / \mathrm{W}^{\mathrm{f}}$ mice (Figure $2 \mathrm{f}$ ) contained a large proportion of necrotic fibres and only a small number of healthy fibres. There was a similar degree of extracellular oedema and leucocyte infiltration between the three groups at $24 \mathrm{~h}$ and 3 day reperfusion.

\section{Muscle Assessment after 3 Days Reperfusion}

Muscle fibres in the gastrocnemius muscle were analysed after 3 days reperfusion to allow assessment of necrosis by histology (see Figure 3a and b). The volume of each muscle was determined by fluid displacement and the volume density of viable and necrotic fibres and extracellular space were determined using point counting methodology. Based on the percent volume density (Figure 3a), there was a significant increase $(P<0.05)$ in the proportion of necrotic fibres in normal littermates and BMMC engrafted $W^{f} / W^{f}$ mice $(59 \pm 7$ and $56 \pm 15 \%$, respectively) compared to normal $\mathrm{W}^{\mathrm{f}} / \mathrm{W}^{\mathrm{f}}$ mice $(34 \pm 10 \%)$. Conversely, there was twice the proportion of healthy fibres in $W^{f} / W^{f}$ mice $(33 \pm 11 \%)$ compared with the normal littermates and BMMC engrafted $W^{f} / W^{f}$ mice $(15 \pm 4$ and $18 \pm 10 \%$, respectively). Extracellular space in the injured gastrocnemius muscle from all groups analysed (normal littermates, $W^{f} / W^{f}$, and engrafted $W^{f} / W^{f}$ mice) was increased on average to five-fold that of their contralateral noninjured muscle. This was due to the extracellular oedema generated in response to IR. A similar result was found when the total volume of viable fibres, necrotic fibres and extracellular space was calculated (Figure 3b).

\section{Leucocyte Profiles}

Gastrocnemius muscle sections were analysed after $24 \mathrm{~h}$ reperfusion to count leucocyte profiles. There was no difference in leucocyte profiles $/ \mathrm{mm}^{2}$ between muscles from normal littermates, $W^{\mathrm{f}} / \mathrm{W}^{\mathrm{f}}$ and engrafted $W^{f} / W^{f}$ mice $(572 \pm 51,928 \pm 266$, $1005 \pm 111$, respectively $P=0.23$ )

\section{Localization of Toluidine Blue Positive Mast Cells}

Mast cells were not detected in any of over 100 sections of muscles from $\mathrm{W}^{\mathrm{f}} / \mathrm{W}^{\mathrm{f}}$ mice (from a total of nine mice) (Figure 4a). Mast cells were present in the skeletal muscles of all BMMC engrafted $W^{f} / W^{f}$ mice (Figure 4b). In the gastrocnemius muscle from engrafted $W^{f} / W^{f}$ mice the number of mast cells $/ \mathrm{mm}^{2}$ skeletal muscle was $0.11 \pm 0.08$ (ranging $0.01-0.43$, approximately 3-134 mast cells per 60 muscle sections counted per mouse) compared with $1.84 \pm 0.32$ in normal littermate mice ( $n=5$ for both). A small number of toluidine blue-stained mast cells was detected in the lung (Figure 4d), tongue and ear of all BMMC engrafted $W^{f} / W^{f}$ mice. There was a remarkably high numerical density of mast cells in the spleen of $7 / 8$ BMMC engrafted $W^{f} / W^{f}$ mice, 

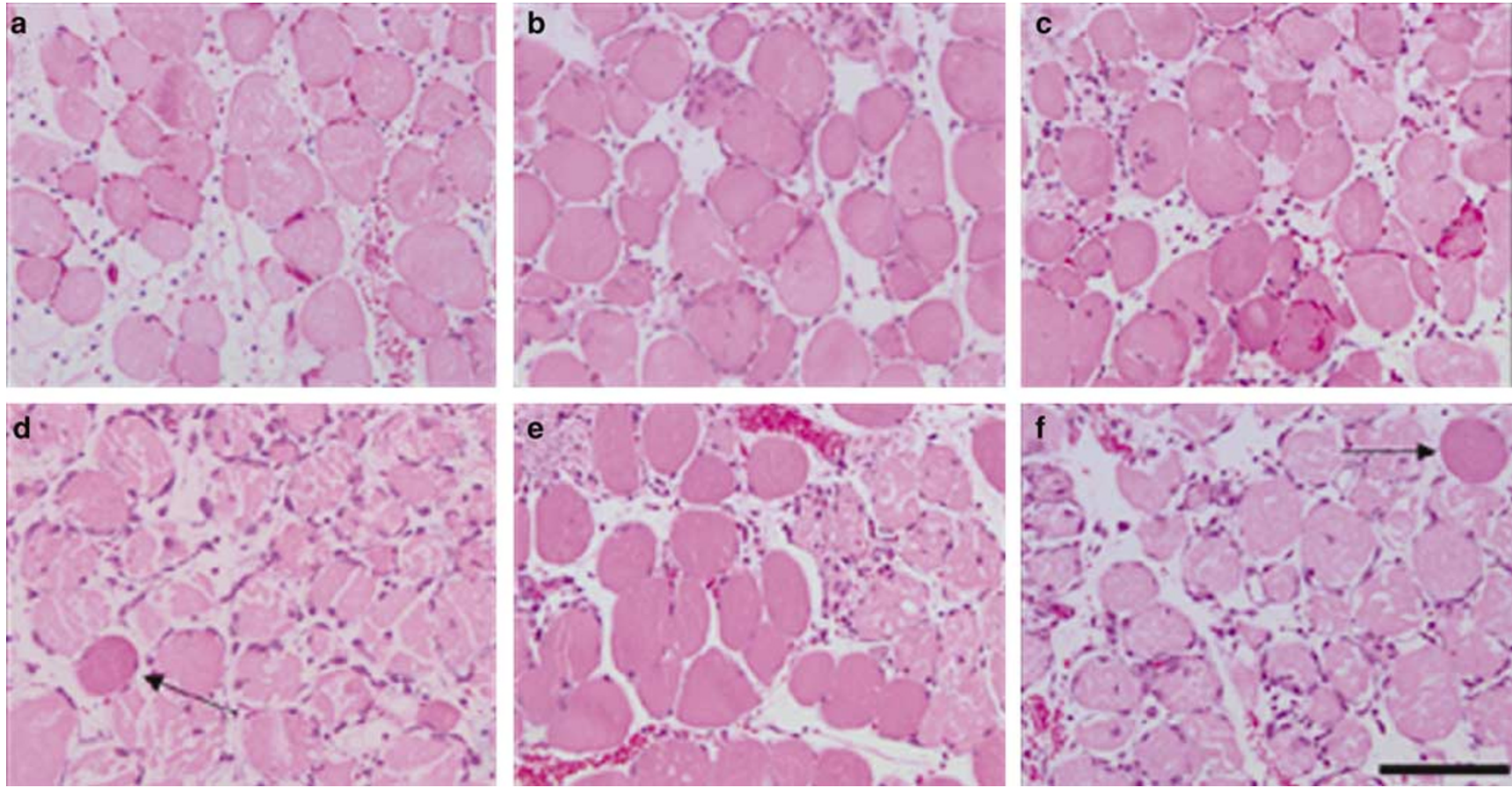

Figure 2 Micrographs showing histological appearance of H\&E stained sections of IR injured gastrocnemius muscle subjected to 70 min warm ischaemia followed by either $24 \mathrm{~h}$ reperfusion (a-c) or 3 day reperfusion (d-f). Micrographs show normal littermate (a and d), $\mathrm{W}^{\mathrm{f}} / \mathrm{W}^{\mathrm{f}}(\mathbf{b}$ and $\mathbf{e})$ and BMMC engrafted $\mathrm{W}^{\mathrm{f}} / \mathrm{W}^{\mathrm{f}}$ (c and f). Note: similar appearance of skeletal muscle after $24 \mathrm{~h}$, due to the failure of histological manifestations of necrosis at this early time point. At 3 days reperfusion, it is clearly evident that gastrocnemius muscle from normal littermate (d) and BMMC engrafted $\mathrm{W}^{\mathrm{f}} / \mathrm{W}^{\mathrm{f}}(\mathbf{f}$ ) have more necrotic fibres (lighter pink colour) and less healthy fibres (darker pink colour as indicated by arrows) than the $\mathrm{W}^{\mathrm{f}} / \mathrm{W}^{\mathrm{f}}$ muscle (e). $n \geq 4$ for all groups. Magnification $\times 200$. Scale bar $=100 \mu \mathrm{m}$.

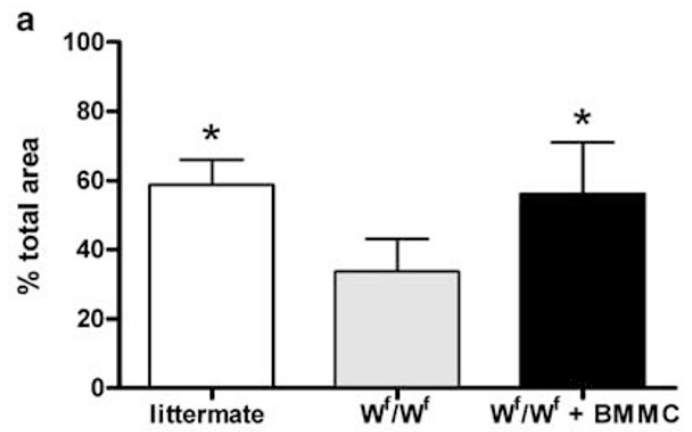

b

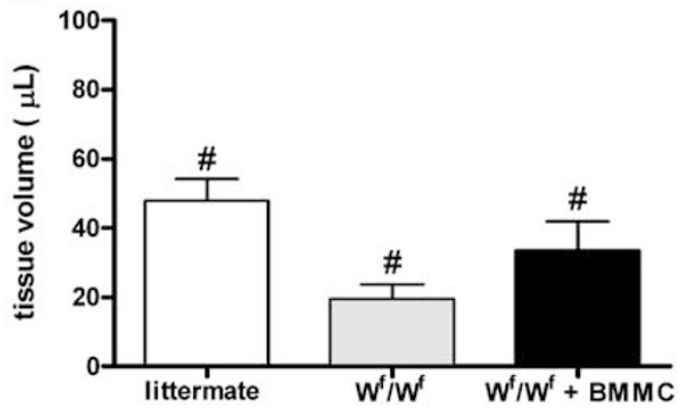

Figure 3 Histological analyses of necrotic fibres from gastrocnemius muscle after $70 \mathrm{~min}$ ischaemia and 3 days reperfusion, expressed as percentage total area (a), and total tissue volume $(\mu \mathrm{l})$ (b). Normal littermates, $n=4 ; \quad \mathrm{W}^{\mathrm{f}} / \mathrm{W}^{\mathrm{f}}, n=3 ; \mathrm{W}^{\mathrm{f}} / \mathrm{W}^{\mathrm{f}}+\mathrm{BMMC}$, $n=3$. Values are mean \pm s.e.m. * Significantly different from $\mathrm{W}^{\mathrm{f}} / \mathrm{W}^{\mathrm{f}}(P<0.05) .{ }^{\#} P<0.05$ in all groups. ranging from 3 to 620 mast cell profiles $/ \mathrm{mm}^{2}$ (Figure 4f). This was considerably more than $1.4 \pm 0.3$ mast cell profiles $/ \mathrm{mm}^{2}$ found in normal littermate spleen. Similarly, the engrafted $\mathrm{W}^{\mathrm{f}} / \mathrm{W}^{\mathrm{f}}$ bone marrow had many more mast cell profiles than $\mathrm{W}^{\mathrm{f}} / \mathrm{W}^{\mathrm{f}}$ and normal littermate bone marrow (data not shown).

\section{Mast Cell Profiles in Reperfused Muscle}

In order to determine whether mast cells are affected by IR, the numerical density of mast cells per unit area of muscle parenchyma of contralateral and injured gastrocnemius muscle at various times during $24 \mathrm{~h}$ reperfusion is shown in Figure 5. In the gastrocnemius muscle of C57 mice, the numerical density of mast cells dropped significantly within $1 \mathrm{~h}$ of reperfusion, and then recovered to normal levels after a further $1 \mathrm{~h}$ and remained at this level for at least $24 \mathrm{~h}$. In the contralateral leg, the numerical density of mast cells remained relatively unchanged during $24 \mathrm{~h}$ of reperfusion.

\section{Discussion}

Mast cells have previously been implicated in IR injury of skeletal muscle, however, the degree of their involvement is not clear. In order to confirm a causal role for mast cells in IR pathology, we 

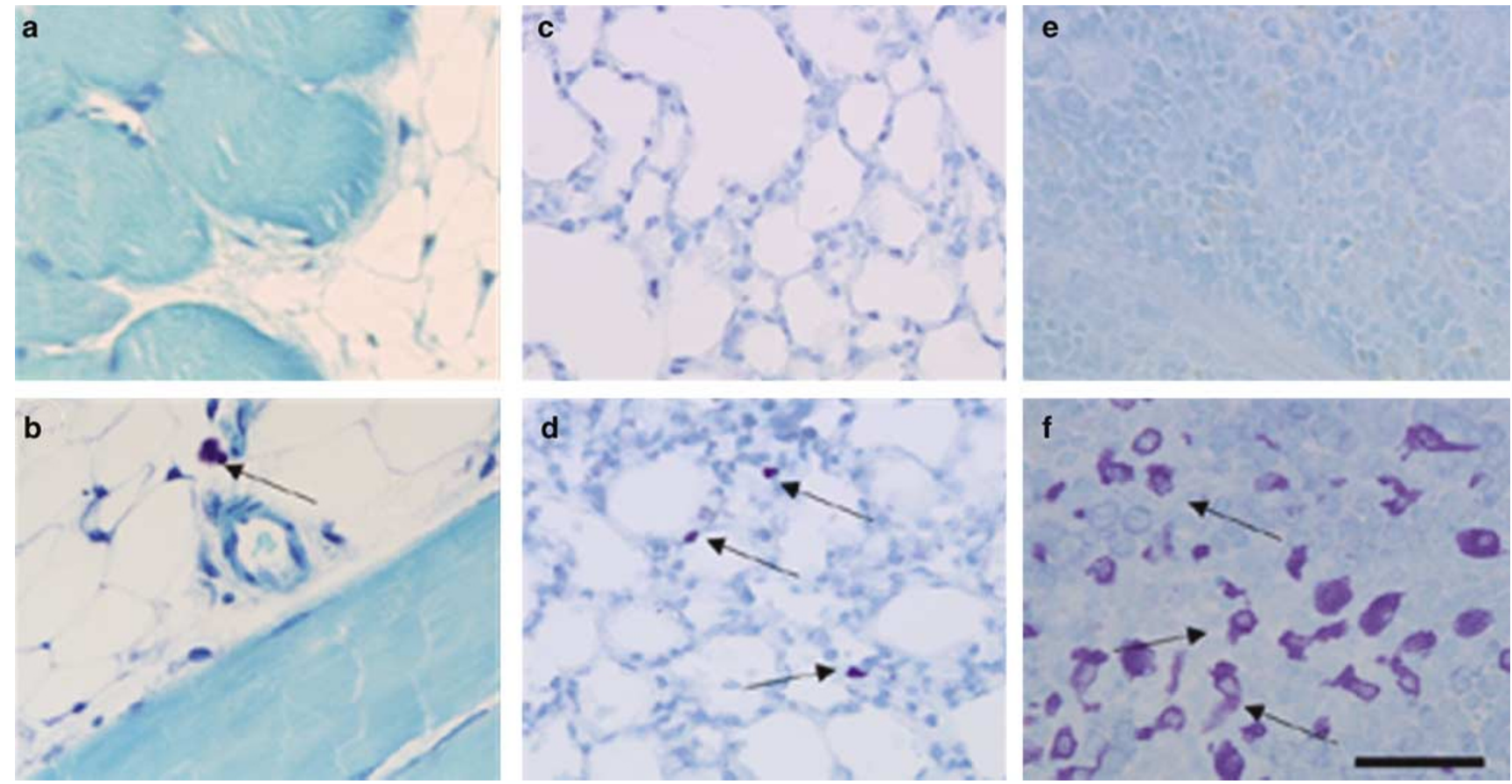

Figure 4 Micrographs showing toluidine blue-stained sections of skeletal muscle, lung and spleen of $\mathrm{W}^{\mathrm{f}} / \mathrm{W}^{\mathrm{f}}$ and $B M M C$ engrafted $\mathrm{W}^{\mathrm{f}} / \mathrm{W}^{\mathrm{f}}$ mice. No mast cells are detectable in the skeletal muscle, lung or spleen of $\mathrm{W}^{\mathrm{f}} / \mathrm{W}^{\mathrm{f}}$ mice (a, c and e, respectively). (b) A metachromaticstained mast cell is visible (arrow) in the connective tissue surrounding skeletal muscle of BMMC engrafted $\mathrm{W}^{\mathrm{f}} / \mathrm{W}^{\mathrm{f}}$. (d) $\mathrm{Three}$ metachromatic-stained mast cells (arrows) are visible in the lung of BMMC engrafted $\mathrm{W}^{\mathrm{f}} / \mathrm{W}^{\mathrm{f}}$. (f) Several metachromatic mast cells (arrows) are located in the spleen of BMMC engrafted $\mathrm{W}^{\mathrm{f}} / \mathrm{W}^{\mathrm{f}} . n \geq 4$ for all groups. Magnification $\times 400$. Scale bar $=50 \mu \mathrm{m}$.

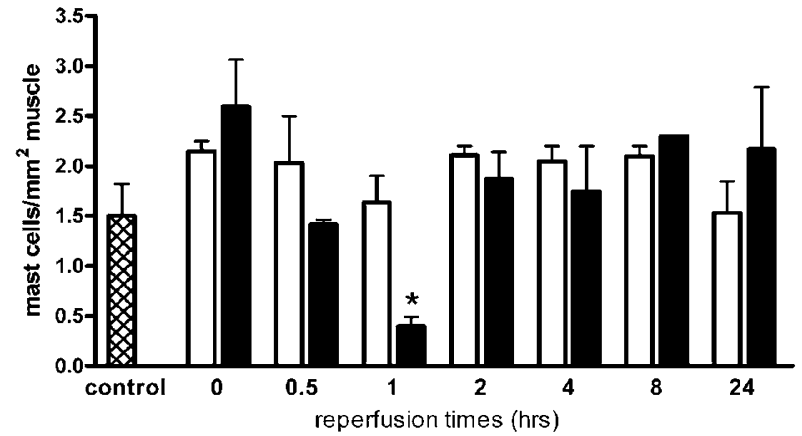

Figure 5 Toluidine blue positive mast cell profiles in skeletal muscle area of gastrocnemius muscle after $70 \mathrm{~min}$ ischaemia and $0-24 \mathrm{~h}$ reperfusion. Mast cell profiles for contralateral muscle (white bars) and injured muscle (black bars), and control muscle (hatched bar). Control and $24 \mathrm{~h}$ reperfusion $n=3,0-8 \mathrm{~h}$ reperfusion $n=2$. Values are mean \pm s.e.m. * Significantly different to 0.5 and $2 \mathrm{~h}$ reperfusion injured gastrocnemius values $(P<0.05)$.

engrafted BMMC into $\mathrm{W}^{\mathrm{f}} / \mathrm{W}^{\mathrm{f}}$ mice. After 12 weeks these mice and their $\mathrm{W}^{\mathrm{f}} / \mathrm{W}^{\mathrm{f}}$ and normal littermates were subjected to hind limb IR injury and the relevant muscles assessed for viability. Our data show that engraftment of BMMC into $\mathrm{W}^{\mathrm{f}} / \mathrm{W}^{\mathrm{f}}$ mice restores the susceptibility of skeletal muscles to IR injury back to the levels observed in normal littermates. At the same time, nonengrafted $\mathrm{W}^{\mathrm{f}} / \mathrm{W}^{\mathrm{f}}$ mice continued to show remarkable resistance to IR injury. The use of mast cell-deficient/depleted mice and the technique of engrafting BMMC into these mice is an effective strategy to study the role of mast cells in different pathologies since only the mast cell deficiency is corrected.

In this study, we adopted the protocol of Lee et $a l,{ }^{17}$ who successfully engrafted BMMC into W/ $\mathrm{W}^{\mathrm{v}}$ mice, restoring the susceptibility to development of joint inflammation. Like Lee et al and others, ${ }^{16}$ we were able to show that engrafting BMMC into $\mathrm{W}^{\mathrm{f}} / \mathrm{W}^{\mathrm{f}}$ mice did not correct the anaemia of these mice as demonstrated by haematocrit values. Under these circumstances, it is paramount to confirm that only the mast cell deficiency has been restored since other deficiencies exhibited by $\mathrm{W}^{\mathrm{f}} / \mathrm{W}^{\mathrm{f}}$ mice, such as anaemia, may also be corrected and be protective. Failure to correct anaemia in BMMC engrafted mice is accepted as an indication that other deficiencies are not corrected. ${ }^{16,17}$ Our seeding cell population was derived from cell culture of $>95 \%$ toluidine blue positive and $98.5 \%$ c-kit positive mast cells. When taking into consideration the 'mast cell'enriching conditions under which the bone marrow was cultured over a 4-week period and the failure of the injected population to correct anaemia it is unlikely that the remaining $5 \%$ of cells were other haematopoietic lineages. However, it is likely that these cells may have been mast cell precursors.

Successful engraftment of BMMC into $\mathrm{W}^{\mathrm{f}} / \mathrm{W}^{\mathrm{f}}$ mice was confirmed by the presence of toluidine blue positive mast cells in the spleen, lung and skeletal muscles of these mice. Since to date, no mast cells 
have been detected in any of the $\mathrm{W}^{\mathrm{f}} / \mathrm{W}^{\mathrm{f}}$ spleen, lung or skeletal muscle specimens without engraftment, our data indicate that the presence of even a small number of mast cells in the engrafted mice is significant. The wide range of numerical mast cell profile densities in the spleen has been recently reported; ${ }^{22}$ however, studies generally only refer to the presence of mast cells, without indicating actual numbers. ${ }^{14,16,17,23}$ In one study by Kobayashi et $a l^{18}$ mast cell numbers in lung of engrafted $\mathrm{W} / \mathrm{W}^{\mathrm{v}}$ mice were reported to be half that normally found in littermates. Our study presents the first time evidence of engraftment of mast cells into skeletal muscles.

A recent study by Tanzola et al, revealed that engrafting of mast cells into tissues was dependent on the tissue and assessment time. ${ }^{22}$ Engrafted mast cells were detected in bone marrow, lung and liver as early as 3 weeks after injection, but were not detected in skin until 28 weeks. Skeletal muscle was not assessed but, as with skin repopulation may take several months. Our study revealed mast cells in skeletal muscle after 12 weeks engraftment. Due to the current inability to identify mast cells in the circulation, ${ }^{24,25}$ we must speculate as to where the mast cells reside between the time of injection and detection. The possibility exists that the injected BMMCs are not the same mast cells visible in the skeletal muscle after 12 weeks. Even though $>95 \%$ of the injected cells (total $1 \times 10^{7}$ ) are toluidine blue positive, there are still $5 \times 10^{5}$ that are not. It is possible that some of these cells are mast cell precursors, and are injected along with the BMMC, seeding the bone marrow. These cells could produce a second wave of engraftment at a much later date.

Our studies indicate that up to $85 \%$ of mast cells are lost within $1 \mathrm{~h}$ of reperfusion, this is most likely due to degranulation. Unlike our rat studies where even the most markedly degranulation mast cells could be detected with toluidine blue, ${ }^{6}$ few such profiles were detected in the mouse. The rapid increase in toluidine blue positive mast cell density between 1 and $2 \mathrm{~h}$ of reperfusion was unexpected. The source of this increased number of mast cells is thought to be local, possibly via migration of connective tissue mast cells into the muscle parenchyma. Alternatively, there may be a toluidine negative mast cell population, already resident in the muscle parenchyma, which 'matures' to a toluidine blue positive phenotype. It is unlikely that $1 \mathrm{~h}$ of reperfusion is enough time for BMMC to become mobilized, repopulate the muscle and undergo maturation to a connective tissue phenotype. Nonspecific degranulation of mast cells and release of toxic mediators is thought to be one mechanism by which the muscle can be injured. The mechanism by which this type of degranulation is triggered warrants further investigation. These may include membrane attack complex (MAC)-mediated degranulation, as MAC has been previously implicated in IR injury, however, the mechanism is unknown. ${ }^{2}$ Alternatively, the mast cells may be sublethally injured during the ischaemic phase and undergo degranulation as a result of this.

We have previously shown that polymorphic neutrophils (PMN) are not involved in IR injury to skeletal muscle. ${ }^{26}$ Quantitative data generated by us (24 h reperfusion) and Kanwar et $a I^{27}(1 \mathrm{~h}$ reperfusion) support this by demonstrating there is no difference in neutrophil extravasation. In a qualitative study by Mukundan et $a l^{9}$ neutrophil margination and extravasation was reported to be present in littermates but the involvement in $\mathrm{W} / \mathrm{W}^{\mathrm{v}}$ mice is not clear. In our experience, minimal extravasation occurs at $3 \mathrm{~h}$ reperfusion, the degree of which is difficult to interpret qualitatively because the presence of oedema gives the appearance of decreased cellularity in the tissue. However, it is possible that mast cell depletion results in delayed PMN extravasation (evident at $3 \mathrm{~h}$ and not $24 \mathrm{~h}$ reperfusion).

The role of circulating or resident mast cells and the elucidation of direct and/or indirect mechanisms of action are a complex and challenging field, and we are still a long way from understanding them. The acceptance that mast cells are involved in significant pathologies other than allergies and asthma is increasing rapidly. ${ }^{10,28}$ The involvement of mast cells in IR injury is a crucial finding, as to date there is no therapeutic target to treat or prevent this type of injury.

IR injury is a frequently encountered clinical problem which occurs as a consequence of transplantation and replantation surgery or as a complication of vascular and cardiovascular disease affecting many organs including the heart. ${ }^{29}$ It is clear that mast cells play a pivotal role in many pathologies with manifestations other than histamine release. The current data using engraftment models indicate that mast cells activate other inflammatory cells to cause injury and release injurious mediators into the circulation to cause indirect effects or may directly cause injury. It has been shown by Boros et $a l^{11}$ that mast cell degranulation prior to ischaemia is a protective mechanism in the intestine and can decrease the IR injury. In this study, we show conclusive evidence for a pivotal role of mast cells in IR injury of skeletal muscle. Mast cell manipulation using therapeutic agents would be a logical step towards clinical management of IR injury.

\section{Acknowledgements}

We thank Associate Professor Prue Hart from Flinders University, South Australia, for supplying us with the mast cell-depleted mice. We thank Dr Keren Abberton, Dr Geraldine Mitchell and Dr Anthony Jaworowski for reviewing the article and Ms Wei Wang for her help with statistical analyses. This study was funded by a Grant (209113) from the 
National Health and Medical Research Council of Australia.

\section{References}

1 Grace PA. Ischaemia-reperfusion injury. Br J Surg 1994;81:637-647.

2 Chan RK, Ibrahim SI, Verna $\mathrm{N}$, et al. Ischaemiareperfusion is an event triggered by immune complexes and complement. Br J Surg 2003;90:1470-1478.

3 Knight KR, Zhang B, Morrison WA, et al. Ischaemiareperfusion injury in mouse skeletal muscle is reduced by $\mathrm{N}$ omega-nitro-L-arginine methyl ester and dexamethasone. Eur J Pharmacol 1997;332:273-278.

4 Zhang B, Knight KR, Dowsing B, et al. Timing of administration of dexamethasone or the nitric oxide synthase inhibitor, nitro-L-arginine methyl ester, is critical for effective treatment of ischaemia-reperfusion injury to rat skeletal muscle. Clin Sci (Lond) 1997;93:167-174.

5 Barker JE, Knight KR, Romeo R, et al. Targeted disruption of the nitric oxide synthase 2 gene protects against ischaemia/reperfusion injury to skeletal muscle. J Pathol 2001;194:109-115.

6 Messina A, Knight KR, Dowsing BJ, et al. Localization of inducible nitric oxide synthase to mast cells during ischemia/reperfusion injury of skeletal muscle. Lab Invest 2000;80:423-431.

7 Gilchrist M, Savoie M, Nohara O, et al. Nitric oxide synthase and nitric oxide production in vivo-derived mast cells. J Leukoc Biol 2002;71:618-624.

8 Lazarus B, Messina A, Barker JE, et al. The role of mast cells in ischaemia-reperfusion injury in murine skeletal muscle. J Pathol 2000;191:443-448.

9 Mukundan C, Gurish MF, Austen KF, et al. Mast cell mediation of muscle and pulmonary injury following hindlimb ischemia-reperfusion. J Histochem Cytochem 2001;49:1055-1056.

10 Dowdall JF, Winter DC, Baird AW, et al. Biological role and clinical implications of mast cells in surgery. Surgery 2002;132:1-4.

11 Boros M, Kaszaki J, Ordogh B, et al. Mast cell degranulation prior to ischemia decreases ischemiareperfusion injury in the canine small intestine. Inflamm Res 1999;48:193-198.

12 Bani D, Masini E, Bello MG, et al. Relaxin protects against myocardial injury caused by ischemia and reperfusion in rat heart. Am J Pathol 1998;152: 1367-1376.

13 Kitamura Y, Go S, Hatanaka K. Decrease of mast cells in $\mathrm{W} / \mathrm{Wv}$ mice and their increase by bone marrow transplantation. Blood 1978;52:447-452.

14 Nakano T, Sonoda T, Hayashi C, et al. Fate of bone marrow-derived cultured mast cells after intracutaneous, intraperitoneal, and intravenous transfer into genetically mast cell-deficient $\mathrm{W} / \mathrm{Wv}$ mice. Evidence that cultured mast cells can give rise to both con- nective tissue type and mucosal mast cells. J Exp Med 1985;162:1025-1043.

15 Hart PH, Grimbaldeston MA, Swift GJ, et al. Dermal mast cells determine susceptibility to ultraviolet B-induced systemic suppression of contact hypersensitivity responses in mice. J Exp Med 1998;187: 2045-2053.

16 Secor VH, Secor WE, Gutekunst CA, et al. Mast cells are essential for early onset and severe disease in a murine model of multiple sclerosis. J Exp Med 2000; 191:813-822.

17 Lee DM, Friend DS, Gurish MF, et al. Mast cells: a cellular link between autoantibodies and inflammatory arthritis. Science 2002;297:1689-1692.

18 Kobayashi T, Miura T, Haba T, et al. An essential role of mast cells in the development of airway hyperresponsiveness in a murine asthma model. J Immunol 2000;164:3855-3861.

19 Scherle W. A simple method for volumetry of organs in quantitative stereology. Mikroskopie 1970;26: 57-60.

20 Galli SJ. New insights into 'the riddle of the mast cells': microenvironmental regulation of mast cell development and phenotypic heterogeneity. Lab Invest 1990; 62:5-33.

21 Stevens A, Palmer J. Enzyme histochemistry: diagnostic applications. In: Bancroft JD, Stevens A (eds). Theory and Practice of Histological Techniques, 4th edn. Churchill Livingstone: New York, 1996, pp 411-420.

22 Tanzola MB, Robbie-Ryan M, Gutekunst CA, et al. Mast cells exert effects outside the central nervous system to influence experimental allergic encephalomyelitis disease course. J Immunol 2003;171:4385-4391.

23 van Houwelingen AH, Kool M, de Jager SC, et al. Mast cell-derived TNF-alpha primes sensory nerve endings in a pulmonary hypersensitivity reaction. J Immunol 2002;168:5297-5302.

24 Irani AM, Schwartz LB. Mast cell heterogeneity. Clin Exp Allergy 1989;19:143-155.

25 Gurish MF, Austen KF. The diverse roles of mast cells. J Exp Med 2001;194:1-5.

26 Knight KR, Messina A, Hurley JV, et al. Muscle cells become necrotic rather than apoptotic during reperfusion of ischaemic skeletal muscle. Int J Exp Pathol 1999;80:169-175.

27 Kanwar S, Hickey MJ, Kubes P. Postischemic inflammation: a role for mast cells in intestine but not in skeletal muscle. Am J Physiol 1998;275(2 Pt 1): G212-G218.

28 Marone G, Galli SJ, Kitamura Y. Probing the roles of mast cells and basophils in natural and acquired immunity, physiology and disease. Trends Immunol 2002;23:425-427.

29 Frangogiannis NG, Smith CW, Entman ML. The inflammatory response in myocardial infarction. Cardiovasc Res 2002;53:31-47. 